\title{
Financial Inclusion and Economic Growth in Nigeria
}

\author{
Joseph Bidemi Obayori ${ }^{1 *}$ \& Chidinma Chioma B. George-Anokwuru ${ }^{2}$ \\ $1^{1 *}$ Department of Economics, Faculty of Social Sciences, Nnamdi Azikiwe University, Awka, Nigeria \\ ${ }^{2}$ Department of Economics, Faculty of Social Sciences, University of Port Harcourt, Nigeria \\ *Corresponding Author: profobj2000@gmail.com
}

DOI: https://doi.org/10.38157/business-perspective-review.v2i2.149

Citation: Obayori, J. B., \& George-Anokwuru, C. C. B. (2020). Financial Inclusion and Economic Growth in Nigeria. Business Perspective Review 2(2), 46-56. DOI: https://doi.org/10.38157/business-perspective-review.v2i2.149

\section{Research Article}

\begin{abstract}
Purpose: Financial inclusion entails the delivery of financial services to individuals and businesses at segments of the society at a reasonable rate that meets their desired transactions. In view of this, the paper examined financial inclusion and economic growth in Nigeria from 1981-2018.

Methods: The ARDL model was used to analyze the annual time series data collected from the CBN Statistical Bulletin and the World Bank report. The augmented Dickey Fully (ADF) unit root test, to test for stationarity of the variables preceded the ARDL model.

Results: The ADF unit root test results showed that the dependent variable was stationary at order zero $I(0)$, while the independent variables were stationary at order one I(1). Based on the first-hand results, it was revealed that both in the short-run and long-run, access and effective usage of financial services bring about a significant increase in economic growth. But per capita income has a negative but significant relationship with economic growth.

Implications: The study conforms to finance-led growth theory which averred that the financial system is a positive function of economic growth. Based on these findings, the paper recommended that more efforts needed to be done to enhance and extend financial inclusion services such as electronic transaction in the form of POS, ATM, mobile money, etc to all rural communities in Nigeria as well as financial literacy and engagement of low-income people in the formal financial services in order to increase economic growth.
\end{abstract}

Keywords: Financial Inclusion, Economic, Growth, Per-Capita, Nigeria

\section{Introduction}

The general view of financial inclusion has presumed a high level of reputation in recent times as a result of its great import as a determinant of economic growth and development (Sharma, 2016). Nonetheless, attaining inescapable financial inclusion has been a foremost task universally. By way of definition, financial inclusion is the provision of financial services at reasonable costs to the deprived and low-income fragments of the society in contrast to financial exclusion where those services are not obtainable or cheap (Horgan, Fagge \& Ukeje, 2015). In the same way, World 
Bank (2015) postulated that financial inclusion entails the prospect of individuals and businesses to valuable and affordable financial products and facilities that meet their required transactions, payments, savings, credit, and insurance provided in an accountable and maintainable way. Obviously, Kama \& Adigun (2013) claimed that globally, about 54\% of adults are without access to financial services. In like manner, Agbelusi (2018) posited that World Bank estimated that two billion people are excluded from the formal financial services universally. Thus, financial inclusion seeks to unravel development prospects for the poor by providing access to basic financial services, especially microcredit facilities. While established economies such as UK, Sweden, France, among others have initiated definite legal and policy declarations towards inspiring activities (primarily by banks) that ensure continued growth and sustainable financial inclusion; the reverse is the case for developing economies like Nigeria. That was why Kama \& Adigun (2013) established that growing economies exhibit about 70\% of financial exclusion levels. For instance, in Nigeria, CBN (2012) reported that a total of about 39 million adult Nigerians representing about $46 \%$ of the adult populace of 84.7 million were financially excluded as at the end of the year 2012. This makes Nigeria's rate of adult financial inclusion amongst the lowest in Africa (Ajakaiye \& Olowookere, 2013).

In valuing the import of financial inclusion as a mechanism of economic growth, Nigeria has instigated policies and programs to stimulate financial inclusion bearing in mind the peculiarities of the economy and local population features. In the 1970s, one of the key programs of the government was the launching of the rural banking scheme in 1977 which was geared towards achieving a minimum of one bank branch in every local government area in Nigeria (Babajide, Adegboye \& Omankhanlen, 2015). Also, there was the conception of the National Financial Inclusion Strategy (NFIS) by CBN with key stakeholders in 2012. The NFIS target is to reduce the financial exclusion rate from $46.3 \%$ in 2010 to $41.6 \%$ in 2016 . But, the breakdown analysis of CBN reports in the same year suggested that the south-west geopolitical zone, with an $18 \%$ exclusion rate had surpassed the 2020 NFIS target of 20\% with the south-east and south-south regions making impressive progress and the north-west and north-east having the highest financial exclusion rates (Babajide, Adegboye \& Omankhanlen, 2015).

Meanwhile, the ability to sustain financial inclusion to the populace mostly the rural residents in Nigeria is one of the key factors for economic growth. That is why the Central Bank of Nigeria's $(\mathrm{CBN})$ ensures that banks extend their products to remote areas. But a high proportion of the residents in these areas are still unbanked as a result of barriers such as low income per capita, lack of employment and low literacy levels, and long distance to access points (Emeka \& Udom, 2015). Also, there is an uneven distribution of revenue, which has broadened the disproportion of the income per capita between the rich and the poor. Thus, more than $50 \%$ of the nation's treasure is shared by fewer than $10 \%$ of the population (Awe \& Olawumi, 2012; Babajide, Adegboye, \& Omankhanlen, 2015). Similarly, some challenges like poor technology, low financial literacy, poor incomes, inadequate infrastructures especially in rural areas, cultural and religious barriers, and slow resolution of user complaints by financial institutions were encountered in the course of deepening the financial inclusion in Nigeria. This is because, the economy is still characterized by the inadequate deployment of technology that lower the cost of financial 
services, inadequate creation of more channels to reduce distance of access points and lower the cost of transactions, lack of simple methods to enhance usage and reduce exclusion and development of a regulatory framework that supports financial inclusion. Thus, the goals of the paper were to; examine both the long-run and short-run impact of the independent variables (usage of financial products, access to financial products, and per capita income) on the dependent variable (economic growth) in Nigeria.

\section{Literature Review}

\subsection{Finance-Growth Theory}

The theoretical foundation of this paper is the "finance-led growth theory" which was conceptualized by Schumpeter (1912). He hypothesized that financial arrangement plays an acute part in manipulating an extended period of economic growth rates. This assumption premised a kind of "supply-leading" association between the financial sector and economic growth in that an efficient financial sector uses the finite resources from surplus (excess) units to shortfall units; consequently, enhancing the growth of other sectors in the economy (McKinnon, 1973).

In the intervening time, several studies on financial development have identified four discrete paths as the driving force of economic development. These are; cheap source of payment to all, increase in the size of the business deal, risk assessment of liquidity and discoveries as well as the provision of information on possible investment within the economy (Odeniran \& Udeaja, 2010; Greenwood \& Jovanovic, 1990; Bencivenga \& Smith, 1991;. Ross, 2004). Thus, the key points from this theory as relates to Nigeria are: government through the CBN economic policies will help to encourage the formation of formal financial institutions like deposit money banks and microfinance banks which will in turn make financial products available abundantly at an affordable cost. Also, accessibility and usability of financial products effectively can lead to the growth and development of the economy.

\subsection{Empirical Stand Point on Financial Inclusion and Economic Growth}

Odeleye and Olusoji (2018) used cointegration and granger causality tests to determine financial inclusion and output in Nigeria from 1981 and 2014. Based on findings, the key determinants of growth are; money supply, liquidity ratio, and credit to the private sector. Lawrence (2017) used OLS to assess the effect of financial inclusion on economic development in Nigeria between 1986 and 2015. The outcome proved that credit to the private sector has not considerably effect on economic growth but alleviated poverty in Nigeria via rural credit distribution. Ugbede, Mohd, and Ahmad (2017) used VECM to examine the empirical evidence of financial inclusion and the Nigerian economy from 1982-2014. The outcomes proved that the loan and deposit of remote residents' with the branches of deposit money banks significantly stimulate the performance of the Nigerian GDP. Ammar and Azhar (2015) used ARDL to explore the nexus between financial inclusion and economic development in Iraq. The study discovered an insignificant level of financial inclusion index in Iraq projected at 10\%. Nwanne (2015) used descriptive method and content analysis to examine the link between financial inclusion and economic growth in Nigerian 
remote dwellers. The outcome showed that a nation will lack development in the absence of the suitable operation of financial inclusion in remote areas in Nigeria. Ogiriki and Andabai (2014) confirmed a long-run equilibrium linkage between economic growth and financial intermediation. Oruo (2013) used OLS to study the association between financial inclusion and economic growth in Kenya from 2002-2012. His findings show that there is a direct effect of financial inclusion on economic growth. Oriavwote and Eshenake (2012) in their study on financial development and economic growth in Nigeria, showed that financial sector expansion substantially improved economic growth in Nigeria. Also, Maduka and Onwuka (2012) investigated the long and short runs link between financial arrangement and economic growth in Nigeria. The result points out that the financial market informed economic growth negatively in Nigeria. Olofin and Udoma (2006) used VECM to examined the financial structure and economic growth in Nigeria from 1970-2005. They advanced that financial structure has no independent effect on Nigeria's economic growth.

\section{Methodology}

This section presented the method that was adopted in testing economic theories as regards the subject matter. Even though several quantitative analyses could be used for this study, the econometric analysis of the Auto-Regressive Distribution Lag (ARDL) model was used. The choice of the technique was premised on the stationarity of series at the level and first difference. Also, the rationale for the ARDL model is to determine both the short-run and long-run impact of the independent on the dependent variables.

Meanwhile, both the descriptive statistics and the stationarity test preceded the ARDL technique to establish both the characteristics and stability of the sample data. The general form of the ADF unit root test is presented as; $\Delta \mathrm{GDP}_{\mathrm{t}}=\varepsilon_{0}+\varepsilon_{1} \mathrm{GDP}_{\mathrm{t}-1}+\alpha_{\mathrm{t}}+\mathrm{U}_{\mathrm{t}}$

Where: GDP is a time series, $\mathrm{t}$ is a linear time trend, $\varepsilon$ is the first difference operator, $\varepsilon_{0}$ is the intercept, $t-1$ is the lag period of the variables and $U$ is the error term. The data employed in this study were mainly time series data for Nigeria sourced from the CBN statistical bulletin and World Bank data, published by the World Bank.

\subsection{Model Specification}

This study adopted the Autoregressive Distributed Lag (ARDL) model. The model was specified in line with the finance-growth theory. Thus, economic growth is a function of financial inclusion. The functional model was formalized in a multiple regression model as follows:

$\mathrm{GDP}=\mathrm{f}(\mathrm{AFI}, \mathrm{UFI}, \mathrm{IPC})$

Consequently, to put the variables on the same scale, the econometric form of the model was stated in log-linear formulations of the ARDL cointegration and ECM model as follows:

$$
\begin{aligned}
& \Delta \operatorname{lnGDPt}=\alpha 0+\mathrm{a} 1 \operatorname{lnGDPt}+\alpha 2 \ln A F I t+\alpha 3 \ln U F I t+\alpha 4 \ln I P C t+\sum_{i=1}^{n} \Delta \beta 1 \ln G D P t-1 \\
& +\sum_{i=1}^{n} \Delta \beta 2 \ln A F I t-1+\sum_{i=1}^{n} \Delta \beta 3 \ln U F I t-1+\sum_{i=1}^{n} \Delta \beta 4 \ln I P C t-1+\Omega E C M+\mathcal{E t}
\end{aligned}
$$


Where; GDP is the gross domestic product (a proxy for economic growth), AFI is access to financial service ((proxy by a number of branches of deposit money bank), UFI is the usage of financial service (proxy by deposit with deposit money bank), $\alpha_{\mathrm{o}}$ is a constant term, $\alpha_{1}-\alpha_{4}$ is long-run coefficients, $\beta 1$ - $\beta 4$ is short-run dynamic coefficients of the regressors, $\Delta$ is first difference operator, $\mathrm{n}$ maximum lag lengths, $\sum$ is the summation, ECM is error correction term lagged for a period, $\Omega$ is coefficient of error correction term, Ln is natural logarithm and $\mathscr{E}$ t is the white noise.

\subsection{Variable Description and Sources}

Gross Domestic Product (GDP): This measure the monetary value of the total output of goods and service within the geographical boundary of a country in a given year in the nominal term after adjusted for inflation. The data was sourced from CBN statistical bulletin (2018).

Deposit with Deposit Money Bank: The amount saved with deposit money bank is used as a measure of usage of financial service. Thus, savers with deposit money banks are the declared number of deposit account owners at deposit money banks (WDI, 2018).

Number of Branches of Deposit Money Bank: Branches of commercial banks per $1000 \mathrm{~km} 2$ is used as financial inclusion access indicator. It was computed as the magnitude of deposit money bank branches per 100, 000 adults. This shown accessibility the banks are to the users (CBN statistical bulletin, 2018).

Per Capita Income: Per capita income is the overall output of a nation per the magnitude of the population. Thus, it measures normal income and the standard of living of different populations (CBN statistical bulletin, 2018).

\section{Results and Discussion}

\subsection{Pre-Estimation Test}

This comprises the descriptive statistics to evaluate the trend and the nature of the variables. Also, the unit root test helps to ensure the stationarity of the variables.

Table 1: Descriptive Statistics for Variables

\begin{tabular}{|ccccc|}
\hline Measurement & GDP & AFI & UFI & IPC \\
\hline Mean & 436734.7 & 2599.868 & 596496.8 & 561.6611 \\
\hline Maximum & 999068.2 & 5809.000 & 2016072. & 1555.411 \\
\hline Minimum & 81454.13 & 622.0000 & 1979.200 & 207.0174 \\
\hline Std. Dev. & 278649.3 & 1724.190 & 767766.0 & 390.3364 \\
\hline Skewness & 0.820320 & 0.530408 & 0.925332 & 1.381078 \\
\hline Kurtosis & 2.324922 & 1.676353 & 2.099553 & 3.642870 \\
\hline Jarque-Bera & 4.983429 & 4.555843 & 6.706627 & 12.73441 \\
\hline Probability & 0.082768 & 0.102497 & 0.034968 & 0.001717 \\
\hline Observations & 38 & 38 & 38 & 38 \\
\hline
\end{tabular}

Note: GDP = Gross Domestic Product, AFI=Access to Financial Service, UFI= Usage of Financial Service, IPC=Per Capita Income

Source: Author's Computation from E-view 10 
The descriptive statistics reported in Table I indicated that economic growth (GDP) has an approximate mean of $\$ 436734.7$ million with the corresponding standard deviation of 278649.3million. Similarly, access to financial service (AFI) has an approximate mean of 2599.9 with the corresponding standard deviation of 1724.2. Usage of financial service (UFI) has an approximate mean of 596496.8 with the corresponding standard deviation of 767766 . Per capita income (IPC) has an approximate mean of $\$ 561.7$ million with the corresponding standard deviation of $\$ 390.3$ million. The skewness test showed that all the variables have positive values; meaning that they are positively sloped. The probability of Jarque-Bera statistics showed that the null hypothesis of the variables; GDP and AFI, were accepted. Thus, the variables were normally distributed. But the null hypothesis of the variables (UFI and IPC) was rejected. Thus, these variables were not normally distributed. More so, the kurtosis test showed that all the series have a large tail. In sum, the results of the descriptive statistics showed that the distributions are higher than normal. This may have resulted from the problem of trended data. Thus, the stationarity test was conducted to stabilize the series before further estimation.

Table 2: Result of Augmented Dickey-Fuller Unit Root Test at Level and First Difference

\begin{tabular}{|ccccccc|}
\hline $\begin{array}{c}\text { Variable } \\
\mathbf{s}\end{array}$ & $\begin{array}{c}\text { ADF @ } \\
\text { Level }\end{array}$ & $\begin{array}{c}\mathbf{5 \%} \text { Critical } \\
\text { Value }\end{array}$ & Decision & $\begin{array}{c}\text { ADF @ 1 } \\
\text { Diff }\end{array}$ & $\begin{array}{c}\mathbf{5 \%} \text { Critical } \\
\text { Value }\end{array}$ & Decision \\
\hline GDP & -4.6454 & -2.9511 & $\begin{array}{c}\text { Stationary } \\
\text { I(0) }\end{array}$ & & & $1(0)$ \\
\hline AFI & -0.9498 & -2.9434 & $\begin{array}{c}\text { Not } \\
\text { stationary }\end{array}$ & -7.2142 & -2.9458 & $\begin{array}{c}\text { Stationary } \\
\text { I(I) }\end{array}$ \\
\hline UFI & -0.6086 & -2.9484 & $\begin{array}{c}\text { Not } \\
\text { stationary }\end{array}$ & -3.6904 & -2.9458 & $\begin{array}{c}\text { Stationary } \\
\text { I(I) }\end{array}$ \\
\hline IPC & -1.7281 & -2.9434 & $\begin{array}{c}\text { Not } \\
\text { stationary }\end{array}$ & -6.2405 & -2.9458 & $\begin{array}{c}\text { Stationary } \\
\text { I(I) }\end{array}$ \\
\hline
\end{tabular}

Note: GDP = Gross Domestic Product, AFI=Access to Financial Service, UFI= Usage of Financial Service, IPC =Per Capita Income

Source: Author's Computation from E- view 10

The ADF unit root test of stationarity result presented above showed that only the dependent variable (GDP) was stationary at order zero (at level). The non-stationary independent variables (AFI, UFI, and IPC) were differenced once and it became stationary at first difference prior to estimations of the ARDL to prevent false regressions results.

Table 3: ARDL Bounds Test for Co-integration/Long Run Coefficients of the Model

\begin{tabular}{|cccc|}
\hline \multicolumn{2}{|c}{ Model (GDP, AFI, UFI, IPC) } & F-Statistic $=18.6582$ & K=3 \\
\hline $5 \%$ Critical Values & Lower Bound=3.32 & Upper Bound $=4.35$ & \\
\hline Variables & Coefficient & t-statistics & P-value \\
\hline AFI & 0.167822 & 2.619242 & 0.0160 \\
\hline UFI & 0.154519 & 10.109258 & 0.0000 \\
\hline IPC & 0.183286 & 4.937978 & 0.0001 \\
\hline C & 8.490560 & 33.997959 & 0.0000 \\
\hline
\end{tabular}

Note: GDP = Gross Domestic Product, AFI=Access to Financial Service, UFI= Usage of Financial Service, IPC =Per Capita Income

Source: Author's Computation from E-view 10 
The ARDL bound test result presented in Table 3 showed that there is a long-run relationship amongst the variables (AFI, UFI, and IPC). This is because the computed F-statistic of about 18.6582 is higher than the upper critical bounds of 4.35 at $5 \%$ critical value. Therefore, the null hypothesis of no co-integration at a $5 \%$ significance level for the model was rejected.

Moreover, the coefficients of the three independent variables were positively signed and statistically significant with the dependent variable. Thus, there is a long-run association amongst the variables. It is therefore evident that the independent variables move together to bring about economic growth in Nigeria. Thus, for growth and development to be achieved in the long-run, every eligible citizenry needs to be financially included in the Nigerian financial services.

Table 4: Discussion of Short-Run ARDL Error Correction Model

\begin{tabular}{|cccc|}
\hline Variables & Coefficients & t-Statistic & P-Value \\
\hline $\mathrm{D}(\mathrm{GDP}(-1)$ & 3.301376 & 7.083143 & 0.0000 \\
\hline $\mathrm{D}(\mathrm{AFI})$ & 0.692383 & 2.249476 & 0.0353 \\
\hline $\mathrm{D}(\mathrm{UFI})$ & 1.275890 & 2.431444 & 0.0241 \\
\hline $\mathrm{D}(\mathrm{IPC})$ & -0.569860 & -2.770284 & 0.0115 \\
\hline $\mathrm{ECM}(-1)$ & -0.125692 & -7.969765 & 0.0000 \\
\hline $\mathrm{R}^{2}=0.9233$ & $\mathrm{f}-\mathrm{stat}=21.0762$ & Prob(f-stat) $=0.0000$ & DW Stat $=1.9971$ \\
\hline
\end{tabular}

Note: GDP = Gross Domestic Product, AFI=Access to Financial Service, UFI= Usage of Financial Service, IPC =Per Capita Income

Source: Authors Computation from E-view 10

The results of the estimated model as presented in Table 4 showed that the R-squared is $92 \%$, this showed that the model is a good fit. The Durbin Watson (DW) test which measures the degree of serial autocorrelation in the estimated model has a value of 1.9971; which is value is very close to the $2.0 \mathrm{DW}$ benchmark. Thus, the study inferred that there is no problem of serial autocorrelation. Therefore, the estimated model is valid for policymaking. Furthermore, the result of the short-run dynamic showed that the coefficient of the error correction term has the hypothesized negative sign (-0.1256) and statistically significant at a $5 \%$ conventional level. This indicated that the dynamic model has a $12.56 \%$ speed of adjustment. In the meantime, the estimated results also showed that, in the short-run, the coefficient of lag one value of GDP is positively related to economic growth and statistically significant at 5\% level. Similarly, the regression coefficients of both access to financial service (AFI) and the usage of financial service (UFI) have a positive and significant relationship with economic growth. Thus, a percentage increase in both access and usage of formal financial services will significantly cause a corresponding increase in economic growth. This result implies that as the apex bank increases her effort to make the unbanked rural areas to be banked in-term of access and usage of financial services via an increase in the number of banks and depositors in the nooks and crannies of the country in order to be financially inclusive; there will be a significant increase in the growth of the economy. The finding here corroborates Odeleye and Olusoji (2018) who averred that financial inclusion promotes growth in the Nigerian economy. But negates the empirical work of Ammar and Azhar (2015) who posited that no direct link between financial inclusion and economic growth. 
On the other hand, per capita income (IPC) shows a negative but significant relationship with economic growth. This negates economic theory which posited otherwise. Thus, a percentage increase in per capita income will decrease economic growth by $0.569 \%$. This result implies that the low level of per capita income in Nigeria has been inimical to increase in financial inclusion and hence economic growth. Thus, the need to increase income per capita.

\subsection{Post Estimation Test}

This section helps to validate the ARDL results in order to ascertain the usefulness of the estimated model for policymaking.

Table 5: Serial Correlation, Heteroscedasticity and Stability Tests

\begin{tabular}{|cccc|}
\hline Test Type & Test Stat. & p-value & $\begin{array}{c}\text { Critical } \\
\text { Value }\end{array}$ \\
\hline $\begin{array}{c}\text { Serial Correlation (Breusch-Godfrey } \\
\text { Serial } \\
\text { Correlation LM Test) }\end{array}$ & Chi-Square $\left(\mathrm{X}^{2}\right)$ & 0.5322 & 0.05 \\
\hline $\begin{array}{c}\text { Heteroscedasticity (Breusch-Pagan- } \\
\text { Godfrey) }\end{array}$ & Chi-Square $\left(\mathrm{X}^{2}\right)$ & 0.0891 & 0.05 \\
\hline Stability (Ramsey Reset Test) & F-Statistics & 0.6973 & 0.05 \\
\hline
\end{tabular}

Source: Authors' Computation from E-view 10

Table 5 showed that in the estimated ARDL model, serial autocorrelation does not occur as a result of the fact that $\mathrm{X}^{2}$ probability values of 0.5322 exceed the 0.05 critical value. Similarly, the Autoregressive Conditional Heteroskedasticity (ARCH) result showed that heteroskedasticity does not occur in the model as a result of the fact that the Chi-square p-value of 0.0891 is greater than the $5 \%$ convectional p-value. Meaning that the variance of the residual is constant over the sampled period. Also, the stability test via Ramsey reset test with a p-value of 0.6973 , showed that the estimated coefficient is stable. Thus, the result indicated acceptance of the null hypothesis that confirm the stability of the estimated ARDL.

\subsection{Normality Test}

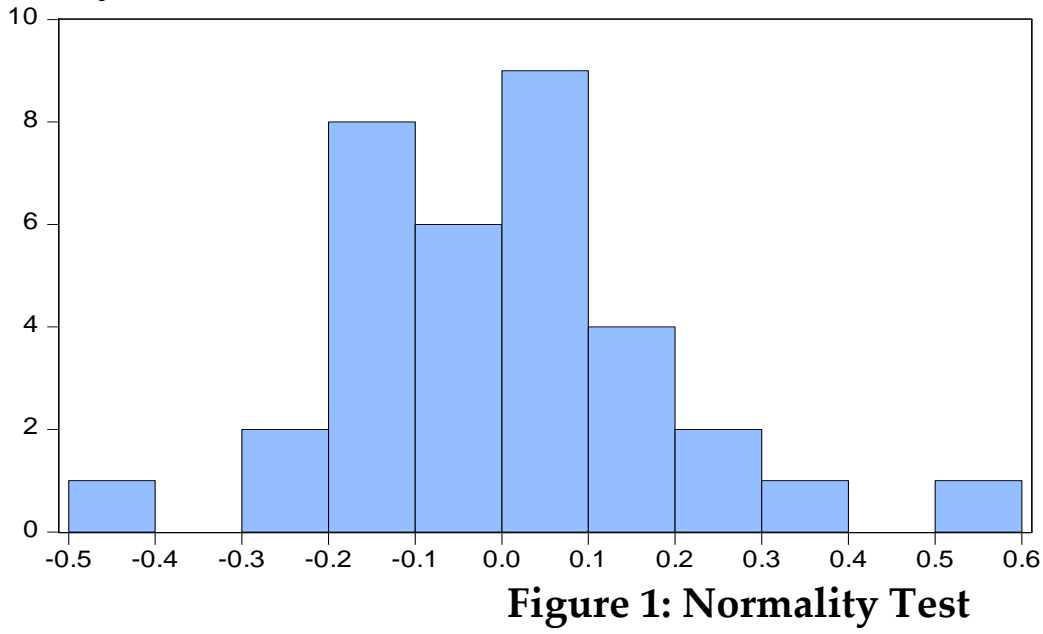

\begin{tabular}{|lc|}
\hline \multicolumn{2}{|l|}{ Series: Residuals } \\
Sample 1985 2018 \\
Observations 34 \\
Mean & $1.46 \mathrm{e}-14$ \\
Median & -0.011097 \\
Maximum & 0.512844 \\
Minimum & -0.418359 \\
Std. Dev. & 0.181318 \\
Skewness & 0.512557 \\
Kurtosis & 3.894914 \\
& \\
Jarque-Bera & 2.623281 \\
Probability & 0.269378 \\
\hline
\end{tabular}


The normality test as shown in Figure 1 showed that the error term is normally distributed. This is because the probability value of the Jerque-Bera statistic (J-B stat) which is 0.2693 is greater than 0.05 critical value. Thus, it was concluded that the sample data fit a standard normal distribution. From the post estimation analyses in both Table 5 and Figure 1, the statistical criteria and reliability of the estimated model were authenticated. Thus, the model is good for policy formulation and recommendation.

\section{Conclusion}

The sustainability of financial inclusion to citizenry particularly the rural dwellers in Nigeria remains the mainstream for economic growth. That is why the Central Bank of Nigeria's (CBN) ensures that banks extend their services and facilities to rural and remote areas to make a high proportion of the residents in these areas to be banked. Financial inclusion entails the delivery of financial services to individuals and business segments of the society at an affordable cost that meets their needed transactions. In order to achieve this singular objective, the CBN has saddled the National Financial Inclusion Strategy (NFIS) with the responsibility of lowering the financial exclusion rate from approximately 46percent in 2010 to as low as $20 \%$ in the year 2020 . In view of this, the paper examined financial inclusion and economic growth in Nigeria and found from the empirical results that both in the shot and long runs, access and effective usage of financial services bring about increase economic growth. But this can be hampered by low per capita income. The findings imply that despite the direct relationship of both access and effective usage of financial services with economic growth, low per capita income in developing countries like Nigeria is inimical to achieving successful financial inclusion that will engender growth in the economy. This is because widespread poverty is a reflection of low income per capita and hence low financial inclusion. In sum, the study conforms to finance-led growth theory which averred that the financial system is a positive function of economic growth. Based on these notes, the paper recommended that more efforts needed to be done to enhance and extend financial inclusion electronic services such as POS, ATM, mobile money, etc. to all rural communities in Nigeria as well as financial literacy. Also, consumer protection should be upheld and there should be the engagement of low-income people in formal financial services especially via microfinance products. Also, the government needs to provide an enabling environment via stable electricity supply to drive the infrastructural facilities provided by banks, telecommunication companies, and other related service providers so that there will be efficient internet and other network communication services.

Authors' Contribution: Both Obayori Joseph Bidemi and Chioma Chidinma George-Anokwuru conceived the idea; Obayori Joseph Bidemi collected data, analyzed the data in line with the methods; Chioma Chidinma B. George-Anokwuru wrote the paper.

Conflicts of Interest: The authors proclaimed no conflict of interest.

\section{REFERENCES}

Agbelusi, M.O. (2018). Financial Technology (FINTECH) as a tool for promoting financial inclusion and economic development in Nigeria, Publication of the Central Bank of Nigeria, 42(1), 61-68. 
Ajakaiye, O. \& Olowookere, A. (2013). Financial inclusion in Nigeria, Newswatch Times. July 7, 2013; 1-56. Lagos. Available: http://www.mynewswatchtimesng .com/financial-inclusion-in-Nigeria.

Ammar, H. K. \& Azhar, H.A. (2015). Financial inclusion and economic development in Iraq, International Journal of Science and Research (IJSR), 6(10), 1758-1767

Awe, A.A., \& Olawumi, O.R. (2012). Determinant of income distribution in the Nigerian economy, International Business, and Management, 15(1), 126-137.

Babajide, A.A, Adegboye, F.B. \& Omankhanlen, A.E. (2015). Financial inclusion and economic growth in Nigeria, International Journal of Economics and Financial Issues, 5(3), 629-637.

Bencivenga, V.R., \& Smith, B.D. (1991). Financial intermediation and endogenous growth, Review of Economic Studies, 58(2), 403-440.

Central Bank of Nigeria (2012). Financial inclusion; Issues and challenges in Nigeria, Occasional Paper No. 45.

Central Bank of Nigeria (2017). Financial inclusion Newsletter, 2(1). 1-20

Central Bank of Nigeria (2018). The Statistical Bulletin, 29, December 2018.

Emeka, E.E. \& Udom, I.A. (2015). Impact of microfinance in promoting financial inclusion in Nigeria, Journal of Business Theory and Practice. 3(2), 139-158.

Greenwood, J. \& Jovanovic, B. (1990). Financial development, growth, and the distribution of income, Journal of Political Economy, 98(5), 1076-1107.

Horgan, E.B., Fagge, A.I. \& Ukeje, H.N. (2015). Financial inclusion and growth of the banking system in Nigeria, Publication of the Central Bank of Nigeria, 39(1-3), 29-40

Kama, U., Adigun, M. (2013). Financial inclusion in Nigeria: Issues and Challenges, (45), 1-45. Abuja, Occasional Paper No. 45 Available:http://www.cenbank.org

Lawrence, U.O. (2017). Financial inclusion as a strategy for enhanced economic growth and development, Journal of Internet Banking and Commerce, 22(8).

Maduka, A. \& Onwuka, K. (2012). Financial market and economic growth: Evidence from Nigerian Data, Department of Economics, Anambra State University-Uli.

McKinnon, R. (1973). Money and Capital in Economic Development, Washington: The Brooking Institute.

Nwanne, T.F.I. (2015). Relationship between financial inclusion and economic growth in Nigerian rural dwellers, International Journal of Small Business and Entrepreneurship Research, 3(7), 17-27

Odeleye, A.T. \& Olusoji, M.O.(2018). Financial inclusion and economic growth in Nigeria, Conference Paper, Research Gate, 1-13

Odeniran, S.O., \& Udeaja, E.A. (2010). Financial sector development and economic growth: empirical evidence from Nigeria, Economic and Financial Review, 48(3), 91-124.

Ogiriki, T. \& Andabai, P. W. (2014), Financial intermediation and economic growth in Nigeria, 1988 - 2013: A vector error correction investigation, Mediterranean Journal of Social Sciences, 5(17).

Olofin, S. \& Uduma, A. (2006). Financial structure and economic growth in Nigeria; A macroeconomic approach, Department of Economics, University of Ibadan, Ibadan, Nigeria.

Onaolapo, A. R. (2015). Effects of financial inclusion on the economic growth of Nigeria, International Journal of Business and Management Review, 3(8), 11- 28.

Oriavwote, V. \& Eshenake, S. (2014). An empirical assessment of financial sector development and economic growth in Nigeria, Department of Social Sciences Economic and Development Studies Programme, Federal University Otuoke, Bayelsa State.

Oruo, J. (2013). The relationship between financial inclusion and GDP Growth in Kenya, A Thesis Submitted to the University of Nairobi for Degree of Master of Business Administration. Available at: http://erepository.uonbi.ac.ke/bitstream/handle/11295/5

Ross, L. (2004). Finance and growth: theory and evidence, National Bureau of Economic Research Working Paper Series n.10766. Available from: http://www.nber.org/papers/w10766.pdf. Retrieved on 11/11/2013.

Sarma, M., Pais, J. (2010). Financial inclusion and development, Journal of International Development, 23, 613-628.

Sharma, D. (2016). Nexus between financial inclusion and economic growth: Evidence from the emerging Indian economy. Journal of Financial Economic Policy, 8(1), 1-10. 
Ugbede, O., Mohd, L. \& Ahmad, K. (2017). Financial inclusion and the Nigerian economy: Empirical evidence, Asian Journal of Economics, Business and Accounting, 4(4), 1-10

World Bank (2015). World Development Indicators; Financial Access, Stability, and Efficiency WDI (2018). World Development Indicators derived from the World Bank.

(C) 2020 by the authors. Licensee Research \& Innovation Initiative, Michigan, USA. This article is an open-access article distributed under the terms and conditions of the Creative Commons Attribution (CC BY) license (http://creativecommons.org/licenses/by/4.0/).

\section{Appendix 1: Research Data}

\begin{tabular}{|c|c|c|c|c|}
\hline YEAR & GDP & AFI & UFI & IPC \\
\hline 1981 & 205222.1 & 622 & 1979.2 & 791.2171 \\
\hline 1982 & 199685.2 & 676 & 2321.2 & 640.2101 \\
\hline 1983 & 185598.1 & 694 & 2879.3 & 438.364 \\
\hline 1984 & 183563 & 810 & 3361.3 & 344.6343 \\
\hline 1985 & 201036.3 & 839 & 3699.9 & 338.5864 \\
\hline 1986 & 205971.4 & 879 & 4270.2 & 234.687 \\
\hline 1987 & 204804.5 & 947 & 5206.7 & 265.1347 \\
\hline 1988 & 219875.6 & 1057 & 7122.7 & 251.7001 \\
\hline 1989 & 236729.6 & 1093 & 9237.8 & 255.8872 \\
\hline 1990 & 267550 & 1169 & 13013.5 & 297.7752 \\
\hline 1991 & 265379.1 & 1253 & 19395.3 & 278.4651 \\
\hline 1992 & 271365.5 & 1495 & 26033.4 & 325.1779 \\
\hline 1993 & 274833.3 & 1577 & 36834.2 & 207.0174 \\
\hline 1994 & 275450.6 & 1634 & 49295.3 & 223.7614 \\
\hline 1995 & 281407.4 & 1661 & 61250.9 & 259.2471 \\
\hline 1996 & 293745.4 & 1727 & 68471.1 & 317.5349 \\
\hline 1997 & 302022.5 & 1727 & 83862.4 & 317.8587 \\
\hline 1998 & 310890 & 1466 & 100889.5 & 275.0453 \\
\hline 1999 & 312183.5 & 1466 & 127811.3 & 290.2069 \\
\hline 2000 & 329178.7 & 1466 & 163963.9 & 374.2242 \\
\hline 2001 & 356994.3 & 1466 & 216258.1 & 380.9346 \\
\hline 2002 & 433203.5 & 2283 & 242786.5 & 457.4737 \\
\hline 2003 & 477533 & 2520 & 311190.3 & 510.4169 \\
\hline 2004 & 527576 & 2765 & 358716.4 & 645.9257 \\
\hline 2005 & 561931.4 & 3233 & 400388.8 & 804.1524 \\
\hline 2006 & 595821.6 & 4200 & 586213.5 & 1014.746 \\
\hline 2007 & 634251.1 & 4952 & 748246.6 & 1127.276 \\
\hline 2008 & 672202.6 & 5436 & 1083838.8 & 1369.742 \\
\hline 2009 & 718977.3 & 5809 & 1165579.6 & 1084.993 \\
\hline 2010 & 776332.2 & 3377 & 1587098.5 & 1431.601 \\
\hline 2011 & 834161.9 & 4577 & 1859569.4 & 1485.97 \\
\hline 2012 & 902794 & 5517 & 2016071.5 & 1555.411 \\
\hline 2013 & 964184 & 4370 & 1820913.1 & 461.3627 \\
\hline 2014 & 969969.1 & 4821 & 1898851.3 & 498.0068 \\
\hline 2015 & 999068.17 & 4903 & 1911945.3 & 511.2129 \\
\hline 2016 & 977740.42 & 4698 & 1877236.6 & 425.662 \\
\hline 2017 & 81454.133 & 4807 & 1896011.1 & 425.348 \\
\hline 2018 & 85230.551 & 4803 & 1895064.3 & 426.1528 \\
\hline
\end{tabular}

Source: CBN Statistical Bulletin, Volume, 29 \& World Bank Data (Various Reports) 